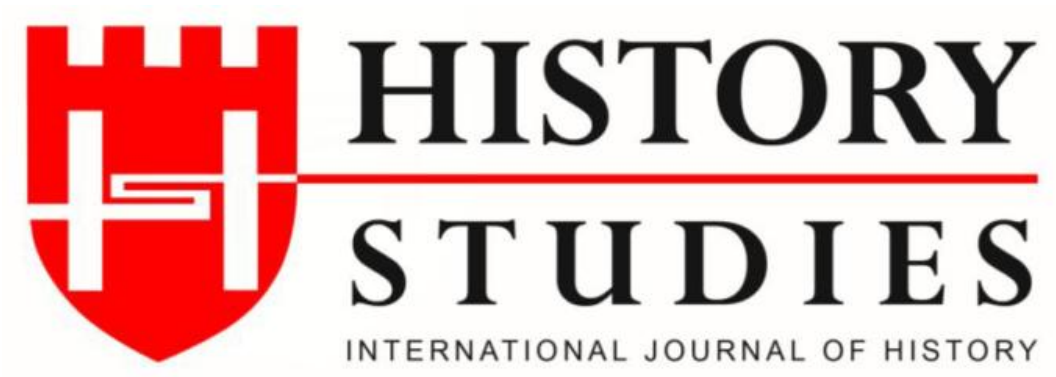

ISSN: 13094173 (Online) 1309 - 4688 (Print)

Volume 12 Issue 5, October 2020

DOI Number: 10.9737/hist.2020.932

Araştırma Makalesi

Makalenin Geliş Tarihi: 20.07.2020 Kabul Tarihi: 07.09.2020

Atıf Künyesi: Hakan Türkkan, “Osmanlı Devleti'nde Kimsesiz Çocuklara Yönelik Yabancı ve

Gayrimüslim Müdahaleleri (1840-1922)”, History Studies, 12/5, Ekim 2020, s. 2577-2597.

\title{
Osmanlı Devleti'nde Kimsesiz Çocuklara Yönelik Yabancı ve Gayrimüslim Müdahaleleri (1840-1922)
}

Interventions of Foreigners and Non-Muslims Towards Orphan Children in the Ottoman Empire (1840-1922)

\author{
Dr. Hakan Türkkan \\ ORCID No: 0000-0002-2681-6230 \\ Karabük Üniversitesi
}

$\ddot{O} \mathbf{z}$

Yapı ve yaratılış itibariyle zayıf ve aciz olan çocuk, hayatını sürdürebilmek için başkalarının bakım ve korumasına ihtiyaç duyar. Çocuğun, yaşadığı toplumda etkili bir güce sahip olamaması ona verilen önemi ve duyulan ilgiyi azaltmıştır. Zayıf ve aciz olması zaman zaman çocuğun fiziki ve ruhi eziyetler görmesine hatta yaşam hakkının elinden alınmasına neden olmuştur. İslâm anlayışı, çocuğun korunması ve hakları konusunda uyarılar yapmış aynı zamanda sıkı tedbirler almıştır. Osmanlı devlet ve toplumu, İslâm uyarı ve tedbirlerinin de katkısıyla çocukların korunması konusunda dikkatli davranmaya çalışmıştır. Ancak her toplumda olduğu gibi Osmanlı toplumunda da tüm uyarı ve tedbirlere rağmen çocukların haksız ve kötü muamelelere maruz kaldığı olmuştur.

Osmanlı Devleti'nin son dönemlerinde ortaya çıkan askerî, diplomatik, sosyal ve ekonomik sorunlar en fazla çocukları etkilemiştir. Yaşanan savaşlar ve göçler nedeniyle ailesini kaybeden binlerce çocuk kimsesiz ve muhtaç duruma düşmüştür. Çocukların korunması amacıyla oluşturulan geleneksel kurumların yetersiz kalması, kimsesiz çocukların korunması konusunda yeni kurum ve anlayışların geliştirilmesini zorunlu kılmıştır. Buna bağlı olarak Osmanlı Devleti'nde ıslahhane ve yetimhane gibi kurumlar açılmıştır.

Bununla birlikte özellikle savaşlar ve göçler nedeniyle ailelerinden kopan veya aileleri vefat eden çocuklar, Osmanlı Devleti'nin bir kısım gayrimüslim tebaası ile yabancı uyruklu bazı kimselerin hedefi olmuştur. Savaş ortamının getirdiği kargaşa ve otorite boşluğundan yararlanan kötü niyetli yabancı ve gayrimüslimler, Müslüman çocukları zorla ve hileyle ele geçirip onların dinlerine ve fikirlerine saldırmışlar böylece çocuğu savaşın bir unsuru haline getirmişlerdir. Dönemin Osmanlı hükümetleri, çocukların yabancı ve gayrimüslimlerin eline düşerek din ve fikirlerinin ifsat edilmesini önlemeye çalışmıştır. Ancak bunun tam olarak başarılabildiği söylenemez. Çünkü diplomatik baskıların artması ve savaşların kaybedilmesi gibi durumlarda Osmanlı hükümetleri, Müslüman çocuklara yönelik yabancı ve gayrimüslimlerin müdahalelerini önlemede zaman zaman aciz kalmıştır. 
Çalışma, Osmanlı Devleti'nde çeşitli nedenlerle kimsesiz ve muhtaç duruma düşen çocukların durumunu ve gayrimüslimlerle yabancıların kimsesiz çocuklar konusunda yürüttükleri faaliyetleri ele almaktadır. Çalışmada Cumhurbaşkanlığı Osmanlı Arşivi kayıtları ve Osmanlı Devleti'nde kimsesiz çocuklarla ilgili literatürden yararlanılmıştır.

Anahtar Kelimeler: Osmanlı Devleti, Kimsesiz Çocuklar, Müdahale, Gayrimüslim, Yabanc1.

\begin{abstract}
The child, who is weak and helpless in terms of structure and creation, needs the care and protection of others in order to survive. The child's inability to have an effective power in the society she lives in has reduced the importance and interest given to child. The weakness and helplessness of the children sometimes caused them to be physically and spiritually harmed or even killed. The understanding of Islam made warnings about the protection and rights of children and took strict measures. The Ottoman state and society tried to be careful about the protection of children with the contribution of Islamic warnings and measures. However, in the Ottoman society, as in every society, despite all warnings and precautions, children were exposed to injustice and evil.
\end{abstract}

Military, diplomatic, social and economic problems experienced in the last period of the Ottoman Empire affected the children the most. Thousands of children who lost their families due to the wars and migrations experienced were left orphan and in need. The insufficiency of the traditional institutions established for the protection of children in the Ottoman Empire required the development of new institutions and understandings about the protection of orphans. Depending on this, institutions such as a borstal and orphanage were opened.

Nevertheless, children who were separated from their families or whose parents died due to wars and migrations became the target of non-Muslims and foreigners. The malevolent nonMuslims and foreigners, who took advantage of the chaos and authority gap of the war environment, seized Muslim children by force and cheating and attacked their religion and ideas. Thus, they made the child an element of war. The Ottoman governments of the period tried to prevent the capture of children by non-Muslims and foreigners and the corruption of their religion and ideas. However, it cannot be said that this has been fully achieved. Because in cases such as the increase of diplomatic pressure and the loss of wars, the Ottoman governments were sometimes incapable of preventing the intervention of non-Muslim and foreigners against Muslim children.

The study focuses on the situation of children who have become orphan and needy due to various reasons in the Ottoman Empire and the activities carried out by non-Muslims and foreigners about the orphan children. Presidential Ottoman Archive records and literature on orphan children in the Ottoman Empire were used in the study.

Keywords: Ottoman Empire, Orphan Children, İntervention, Non-Muslim, Foreign.

\title{
Giriş
}

İbn, veled, evlad, gulâm, sagîr, tıfl, sabî, zürriyet, hafede, ehl, âl, yetîm, rebaib gibi kavramlarla da ifade edilen çocuk, ${ }^{1}$ henüz bulûğ çağına ermemiş insan olarak tanımlanabilir. Ulaşmak anlamına gelen bulûğ, çocuğun cinsî ve bünyevî olarak ergenlik dönemine girmesini ifade eder. ${ }^{2}$ Ergenlik ise bireyin gelişim süreci içinde çocukluk döneminin bitişiyle beraber fizyolojik açıdan erişkinliğe ulaşıncaya kadar geçen bir dönemdir. Diğer yandan ergenlik

${ }^{1}$ Hayati Hökelekli, "Çocuk” Türkiye Diyanet Vakfi İslâm Ansiklopedisi, C. 8, İstanbul 1993, s. 355.

${ }^{2}$ Ali Bardakoğlu, "Bulûğg, Türkiye Diyanet Vakfi İslâm Ansiklopedisi, C. 6, İstanbul 1992, s. 413. 
dönemi, biyo-psikolojik bakımdan çocukluğun sona ermesiyle, toplumsal yaşamda sorumluluk alma dönemi olan yetişkinlik döneminin başlangıcı arasında kalan bir gelişim süreci olarak da düşünülebilir. ${ }^{3}$ Bireyin çocukluk ve yetişkinlik sınırını belirlemesi açısından önemli bir aşama olan bulûğa erme yani baliğ olma yaşının kişiye, iklime ve coğrafyaya göre farklılık göstermesi, bulûğ yaşı konusunda net bir yaş aralığ hukukçuları arasında da bulûğ yaşı olarak farklı görüşler kabul edilmiştir. Örneğin İmam-1 Azam Ebu Hanife, bulûğ yaşının üst sınırı olarak erkeklerde 18, kızlarda 17 yaşı benimserken, Malikî mezhebinde bu sınır kız ve erkeklerde 18 yaş olarak kabul edilmiştir. 19. yüzyılın önde gelen İslâm hukuku çalışmalarından biri olan Mecellede ise erkeklerde ve kızlarda 15 yaş bulûğ yaşı olarak kabul edilmiştir. ${ }^{4} 1917$ tarihinde hazırlanmış olup çocuk ve aile hukuku konusunda pek çok konuyu hükme bağlayan Hukuk-1 Aile Kararnamesi'nde de bulûğ yaşının üst sınırı, İmam-1 Azam Ebu Hanife'nin görüşü esas alınarak kızlarda 17, erkeklerde 18 olarak belirlenmiştir. ${ }^{5}$

Çocuğun, içinde bulunduğu toplumda etki ve güce sahip olmayan bir unsur olması, tarih alanında da çocuk ve çocuklukla ilgili fikir ve çalışmaların geri planda kalması sonucunu doğurmuştur. Öyle ki çocuk kelimesinin Avrupa'da günümüzdeki anlamıyla kullanılmaya başlaması 17. yüzyıl dolaylarına rastlar. Bazı Avrupalı yazarlar çocuk kavramının Avrupa'da iki boyutta geliştiğini düşünürler. Buna göre birinci boyut, burjuva aileler arasında çocukların sevilip okşanacak varlıklar olduğu anlayışıdır. İkinci boyut ise aile dışı çevrede yani din adamı, hukukçu ve ahlakçıların çocuk hakkındaki düşünceleridir. Onlara göre ise çocuk, Tanrının yarattığı, korunması, düzeltilmesi veya yetiştirilmesi gereken kırılgan bir varlıktır. Çocuk ve çocukluk tarihi 1950'lere kadar yalnız ve hemen hemen bakir bir durumda kalmıştır. Bu döneme kadar var olan çalışmalar ise genelde kurumsal araştırmalar şeklinde ortaya çıkmış ve bu çalışmalar çocukluk ve çocuklar hakkındaki fikirlerin dışında kalmıştır. Çocuğun tarihsel inceleme alanına alınmasında, tarihçilerin çocuğun ve çocukluğun toplumsal yapılanmasını fark etmelerinin ve psiko-tarih çalışmalarının önemli payı bulunur. Faydacı ve maddeci modeller yerine tekil ve öznel yaşantılara yöneldikçe çocuk kavramı tarih çalışmalarında daha fazla ön plana çıkmaya başlamıştır. Bununla birlikte genel kanaat, çocukluk tarihinin Batı Avrupa ve Kuzey Amerika'da gördüğü ilgi ile diğer coğrafyalarda gördüğü ilginin aynı olmadığı ve diğer coğrafyalarda çocuk ve çocukluk tarihi konularına daha az ilgi duyulduğu yönündedir. $\mathrm{Bu}$ durumun çocukluk tarihinde bütüncül yaklaşımlar üretilebilmesi imkânını azalttığı düşünülür. ${ }^{6}$ Osmanlı tarihçiliğinde de çocuk ve çocuklukla ilgili çalışmalara çok fazla ilgi oluştuğu söylenemez. Fakat Osmanlı toplumunda kadın, aile vb. konuların ilgi uyandırması ve bu konularda yapılan çalışmalar çocuk ve çocuk yaşamı konusunda bazı ipuçlarının ortaya çıkmasını sağlamıştır. ${ }^{7}$

\footnotetext{
3 Mustafa Koç, "Gelişim Psikolojisi Açısından Ergenlik Dönemi ve Genel Özellikleri”, Erciyes Üniversitesi Sosyal Bilimler Enstitüsü Dergisi, S.17, Kayseri, 2004/2, s. 233.

${ }^{4}$ Burak Kocaoğlu, “Osmanlı Devleti'nde Çocukların İhtida Meselesi (1886-1914), History Studies, 12/3, Haziran 2020, s. 789-805.

5 Yılmaz Yurtseven, "1917 Tarihli Hukuk-1 Aile Kararnamesi ve Osmanlı Aile Hukukuna Getirdiği Yenilikler”, Selçuk Üniversitesi Hukuk Fakültesi Dergisi, C.11, S. 1-2, Haziran 2003, s. 227.

${ }^{6}$ Emine Gazanker, XVI. ve XVII. Yüzyllarda Osmanlı Toplumunda Kimsesiz Çocuklar ve Evlatllklar, T.C. Bahçeşehir Üniversitesi, Sosyal Bilimler Enstitüsü, Yayınlanmamış Yüksek Lisans Tezi, İstanbul 2014, s. $28,30,31$.

${ }^{7}$ Gazanker, agt, s. 33 .
} 
Çocuğun toplumdaki diğer fertlere nazaran pek çok bakımdan daha aciz, masum ve savunmasız olması, tarih boyunca yaşanan savaş, hastalık, afet, göç, yoksulluk gibi olumsuzluklardan en fazla zarar gören taraf olmasına neden olmuştur. Bu durum Osmanlı Devleti'nde de değişmemiş, özellikle son dönemlerde yaşanan olumsuzluklardan en çok etkilenen kesim çocuklar olmuştur. Anadolu'da, Balkanlarda, Kafkaslarda ve Ortadoğu'da yaşanan savaşlar ve göçlerden dolayı çok sayıda çocuk öksüz ve yetim kalmış, bu çocuklar kimsesiz ve muhtaç hale düşmüşlerdir. ${ }^{8}$ Sahipsiz kalan çocukların kim tarafından sahiplenildiği ve nasıl yönlendirildikleri ise siyasi, dinî ve toplumsal açıdan büyük önem arz etmiş hatta zaman zaman anlaşmazlık konusu haline gelmiştir.

\section{Osmanlı Devleti’nde Kimsesiz Çocuklar}

Osmanlı Devleti'nde bazı nedenlerle kimsesiz ve muhtaç hale gelen çocuklar çeşitli sınıflara ayrılmıştır. Bunlardan ilki yetimlerdir. Yetim, farklı anlamlarda da kullanılmakla birlikte babasını kaybetmiş olan büyük küçük herkes için kullanılan bir tabirdir. Türkçede de yetim ifadesi çoğunlukla babası ölen çocuk için kullanılmaktadır. Annesini ya da hem anne hem de babasını kaybeden çocuğa ise öksüz denilmiştir. ${ }^{9}$ Kimsesiz çocuklar sınıfına giren bir diğer grup ise sokağa bırakılan çocuklar olup bunlar, lakît veya lakîta olarak adlandırılmışlardır. ${ }^{10}$ Kimsesiz ve muhtaç çocukların sahiplenildiği durumlarda ise evlatlık çocuklar ortaya çıkmış ve bu durum tebennî kelimesiyle ifade edilmiştir. ${ }^{11}$ Evlat edinme, nesebi belli olsun olmasın başkasına ait bir çocuğun kendi çocuğu olarak kabul edilmesi durumu olup bakıma ve korunmaya muhtaç çocukların ihtiyaçlarının giderilmesinde çok önemli bir işleve sahiptir. ${ }^{12}$ Bunun yanı sıra özellikle muhacir ve mültecilerin bir kısmında daha yaygın olmakla birlikte çocukların evlendirilmeleri, köle olarak verilmeleri veya satılmaları söz konusudur. ${ }^{13}$

Osmanlı devlet ve toplum hayatında kendilerine bakabilecek beceri ve imkândan yoksun bulunan küçük çocukların korunması anlayışı hâkimdir. İslâm anlayışının da etkisiyle çocuklar naif ve narin varlıklar olarak görülmüş, haklarının korunmasına önem verilmiş̧ir. Hatta çocuk söz konusu olduğunda yasaların esnetilmesi yoluna gidildiği bile olmuştur. ${ }^{14}$ Osmanlı toplumunda çocukların korunması ve himayesi konusunda aile birinci derecede sorumlu görülmüş, çocuğun korunması başta anne ve baba olmak üzere aileden başlamıştır. ${ }^{15} \mathrm{Bu}$ yeterli olmadığ takdirde yakın akraba çevresi hatta yaşadığı toplum çocuğun korunmasında sorumluluk üstlenmiştir. ${ }^{16}$ Kurumsal olarak ise Osmanlı vakıfları pek çok alanda olduğu gibi yoksul ve

8 Zekai Karataş, “Osmanlı Devleti'nde Korunmaya Muhtaç Çocuklara Yönelik Sosyal Hizmet Uygulamaları", Manevi Temelli Sosyal Hizmet Araştırmaları Dergisi, C. 1, S. 1, Ocak 2015, s. 16.

9 Abdüsselam Arı, "Yetim", Türkiye Diyanet Vakfi İslâm Ansiklopedisi, C.43, İstanbul 2003, s.501.

${ }^{10}$ Ferit Devellioğlu, Osmanlıca-Türkçe Ansiklopedik Lûgat, Aydın Kitabevi Yayınları, Ankara 1997, s. $541,555$.

${ }^{11}$ Devellioğlu, age, s. 1047.

${ }^{12}$ Gazanker, age, s. 52.

${ }^{13}$ BOA (T.C. Cumhurbaşkanlı̆̆ Osmanlı Arşivi), A.\}MKT.UM (Sadâret Mektubî Kalemi Umum Vilâyât), 526/41, H.19.06.1278.

${ }^{14}$ Gazanker, agt, s. 38.

${ }^{15}$ Karataş, "agm", s. 18.

${ }^{16}$ Nesimi Yazıcı, "Osmanlılarda Yetimlerin Korunması Üzerine Bazı Değerlendirmeler”, AÜIFD, XLVIII, S. 1, 2007, s. 4. 
kimsesizlerin bakımı ve korunması konusunda da uzun yıllar hizmet etmiştir. Fakat vakıfların zamanla işlevsiz kalması bu görevin devlet eliyle gerçekleştirilmesini ve yeni kurumların oluşturulmasını zorunlu hale getirmiştir. ${ }^{17}$ Bununla birlikte Osmanlı Devleti'nin kimsesiz çocukları düzenli ve kurumsallaşmış bir biçimde korumaya yönelik adımlar atması 19. yüzyılda gerçekleşebilmiştir. Bu döneme kadar külhanlarda yaşayan, dilencilikle ya da geçici işlerle hayatlarını sürdüren ayrıca suça meyilli kişiler olarak görüldükleri için toplumdan dışlanan kimsesiz ve muhtaç çocuklar pek dikkati çekmemiştir.

Pek çok alanda yenilik ve düzenlemelerin gerçekleştiği bir dönem olan Tanzimat dönemi, Osmanlı yöneticilerinin kimsesiz ve bakıma muhtaç çocuklarla yakından ilgilenmeye başladıkları ve bu konuda daha somut adımlar attıkları bir evreyi işaret eder. İlk olarak 24 Haziran 1846 tarihinde Serasker Hasan Rıza Paşa, İstanbul'daki külhanlara baskın yaparak 1000 kadar kimsesiz çocuğu Sultanahmet Camii avlusunda toplamış ve onları ikna ederek yetenek ve isteklerine göre askerliğe veya çeşitli mesleklere yönlendirmiştir. Osmanlı Devleti'nde bakıma muhtaç ve özellikle yetim çocuklarla ilgili yasal düzenlemeler de bu dönemde gerçekleştirilmiş olup ilki 31 Aralık 1851 tarihli Eytam Nizamnamesidir. Söz konusu nizamnameye dayanılarak Eytam Nezareti kurulmuş bu sayede yetimlerin maddi haklarının özellikle de miras haklarının korunması yönünde önemli bir adım atılmışırı. ${ }^{18}$ Eytam Nizamnamesi ile Eytam Sandıklarının kurulması da kararlaştırılmış ve bu konuda ayrı bir nizamname hazırlanmıştır. Eytam sandıklarıyla, vefat eden ebeveynden yetim çocuklarına kalan malların zayi ve istismar edilmeden korunması ve reşit olduklarında çocukların kendilerine verilmesi amaçlanmıştır. Yetim mallarının korunması, önceleri kişisel çabalarla gerçekleştirilirken eytam sandıklarının kurulması bu anlayışın kurumsal bir yapı kazanarak devlet eliyle yönetilen bir fona dönüşmesini sağlamıştır. ${ }^{19}$

Tanzimat dönemi, çocuğun korunmasına yönelik bazı yasal düzenlemeler yapılmasının yanı sıra çocuğa bakış açısının da değiştiği bir dönemi ifade eder. Çünkü Tanzimat dönemine kadar sosyo-politik açıdan Osmanlı toplumunda çocukların farklı ve müstakil bir konumunun olmadığı düşüncesi hâkimdir. Ancak Tanzimat ve sonrasında çocuk ve çocuklukla ilgili anlayışlar yavaş yavaş değişmiştir. Bu sayede çocuk, Osmanlı ilmî hayatının da dikkatini çekmeye başlamıştır. Bu nedenle Osmanlı ilmî hayatında çocuk ve çocuklukla ilgili çalışmaların önemli bir kısmı yine Tanzimat dönemi ve sonrasına aittir. Gerek kaynakların çeşitlenmesi gerekse çocukla ilgili algıların değişmeye başlamasını sağlayan bu durum çocukluk tarihi çalışmalarını da olumlu etkilemiştir. ${ }^{20}$

Sözü edilen gelişmelere karş1lık Osmanlı Devleti’nin yıkılma evresi olan 19. yüzyılda uluslararası diplomatik baskıların, kaybedilen savaşların, ekonomik ve sosyal sıkıntıların yoğunlaşması çocukların yaşamını olumsuz yönde etkileyen sorunları doğurmuştur. Yine bu dönemde savaşlar nedeniyle kaybedilen topraklardan Osmanlı Devleti'ne kitleler halinde

${ }^{17}$ Karataş, "agm”, s. 17-18.

18 Yazic1, "agm", s. 26-27.

${ }^{19}$ Tahsin Özcan, "Osmanlı Toplumunda Yetimlerin Himayesi ve Eytâm Sandıkları“, İstanbul Üniversitesi Ilahiyat Fakültesi Dergisi, S.14, Y1l 2006, s. 106.

${ }^{20}$ Gazanker, agt, s. 34-35. 
yönelen göçler, devleti ekonomik yönden olduğu kadar toplumsal yönden de etkilemiştir. Henüz 1780-1800 yılları arasında bile Kırım, Kazan, Kafkasya bölgelerinden Osmanlı Devleti'ne sığınanların sayısı 500.000'i bulmuştur. ${ }^{21}$ 1806-1812 yılları arasında 200.000 dolayında Müslüman, Ruslar tarafından yaşadıkları topraklardan sürülmüştür. Yine 1828-1829 Osmanl1Rus Savaşı sırasında Rus zulmünden kaçan Müslümanlar topraklarını terk etmişlerdir. ${ }^{22} 1783$ 1922 yılları arasında sadece Kırım'dan 1800.000 kişi Osmanlı topraklarına sığınmak zorunda kalmıştır. ${ }^{23}$ 1877-1878 Osmanl1-Rus Savaşı sırasında da 300.000 civarında Müslüman katledilmiş ve 1500.000 'e yakın insan yaşadıkları toprakları terk etmek zorunda kalmıştır. ${ }^{24}$ Şark Meselesi gibi siyasi kin ve hesapları da içeren göç ettirme hareketleri, Balkan Savaşları ve Birinci Dünya Savaşı gibi faktörlere bağlı olarak 20. yüzyılda da devam etmiştir. Göç yolculuğu sırasında yolculuğun zorluğu, barınma sorunu, salgın hastalıkların ortaya çıkması, açlık gibi sebeplerle can kayıpları yaşanmış, aileler dağılmış hatta yok olmuştur. Kesin rakamlarla belirtmek mümkün olmasa da can kayıplarının büyük çoğunluğunun yaşam şartlarına dayanamayan kadın ve çocuklardan oluştuğu düşünülür. Bunun yanı sıra göç sırasında hayatta kalabilen fakat ailesini kaybeden çok sayıda çocuk ortaya çıkmıştır. Bu durum Osmanlı topraklarında kimsesiz ve muhtaç duruma düşen çocuk sayısının giderek artması sonucunu doğurmuştur. ${ }^{25}$

Buna bağlı olarak kimsesiz çocukların korunmaları ve bakımlarının sağlanması amacıyla Osmanlı Devleti'nde yeni kurumlara ihtiyaç duyulmuştur. Islahhaneler bu anlamda önde gelen müesseselerden olup ilk Osmanlı 1slahhanesi Mithat Paşa'nın Tuna Valiliği döneminde 1863 yılında Niş’te açılmıştır. Niş Islahhanesinde yetim, öksüz veya fakir olan Müslüman veya gayrimüslim çocukların barınma, eğitim ve meslek edinebilmelerine yönelik faaliyetler yürütülmüştür. 1867 'den itibaren Anadolu ve Rumeli'nin pek çok vilayetinde 1slahhaneler kurulmuştur. Kurulan 1slahhanelerin büyük bir kısmı erkek çocuklara mahsus olmakla birlikte yine Mithat Paşa tarafından 1868 yılında Rusçuk'ta kız çocukları için de bir sslahhane yaptırılmıştır. 1871 yılına kadar geçici talimatnamelerle idare edilen ıslahhanelerle ilgili olarak bu tarihten itibaren yasal düzenlemeler gerçekleştirilmiş ve islahhaneler, "Islahhanelere Dair Nizamname" çerçevesinde idare edilmeye başlamıştır. II. Abdülhamit döneminde ise Islahhanelerin sanayi mekteplerine dönüştürüldüğ̈ görülür. ${ }^{26}$ Islahhaneler dışında Sultan Abdülaziz döneminde kurulmuş olan Darüşşafaka ile II. Abdülhamit döneminde kurulan Darülaceze ve Darülhayr-1 Âli'ler de kimsesiz ve muhtaç çocukların korunması ve ihtiyaçlarının giderilmesi amacına hizmet etmiştir. Balkan Savaşları ve Birinci Dünya Savaşı sırasında ise

\footnotetext{
${ }^{21}$ Nedim İpek, Rumeli'den Anadolu'ya Türk Göçleri (1877-1890), Türk Tarih Kurumu Yayınları, Ankara 1999, s. 1.

${ }^{22}$ H. Yıldırım Ağanoğlu, Osmanlı'dan Cumhuriyete Balkanların Makus Tarihi Göç, Kum Saati Yayınları, İstanbul 2001, s. 32.

23 Murathan Keha, “1877-1878 Osmanlı Rus Harbi’ne Kadar Yaşanan Kırım Kafkas Göçleri ve Erzurum'un Durumu”, Ekev Akademi Dergisi, Y1l 17, S. 57, Güz 2013, s. 94.

24 Hüseyin Vehbi İmamoğlu, "93 Harbinden Sonra Balkanlardan Anadolu'ya Göçler”, Geçmişten Günümüze Göç I, Canik Belediyesi Kültür Yayınları, Samsun 2017, s.140-141.

25 İsmet Sarıbal, Osmanlı Devleti'nde Muhaceret, İskân ve Entegrasyon Bursa Sancă̆ı Örneği (18451908), İdeal Kültür Yayınc1lık, İstanbul 2018, s. 135.

${ }^{26}$ Cemil Öztürk, "Islahhane", Türkiye Diyanet Vakfi İslâm Ansiklopedisi, C. 19, İstanbul 1999, s.190-191.
} 
kimsesiz çocukların sayısı arttığından söz konusu çocukların ihtiyaçlarını karşılamak amacıyla 25 Kasım 1914'ten itibaren darüleytamlar açılmıştır. ${ }^{27}$

Kimsesiz ve muhtaç durumdaki çocukların barınma ve beslenme ihtiyaçlarının giderilmesi, korunmaları için yeterli olmamıştır. Söz konusu çocukları araç olarak kullanmaya, istismar etmeye ya da onların dinî ve sosyal mensubiyetlerini değiştirmeye yönelik birtakım tehditler ortaya çıkmıştır. Bu tehditlerin büyük bir kısmı Osmanlı topraklarında faaliyet gösteren yabancı ülke vatandaşı bazı kişi, grup ya da kurumlarla bir kısım gayrimüslim tebaadan kaynaklanmıştır. Kimsesiz çocuklara yönelen bu tehlike Osmanlı Devleti tarafindan takip edilmiş ve önlenmeye çalışılmıştır.

\section{Osmanlı Devleti’nde Kimsesiz Çocuklara Yönelik Yabancı ve Gayrimüslim Müdahaleleri}

Osmanlı Devleti'nde kimsesiz çocuklara yönelik müdahaleler çoğunlukla onları dinî ve ideolojik bakımdan etkileme ve ele geçirme amacına yönelik olmuştur. Bu bakımdan kimsesiz çocuklar, müdahale eden kişi ya da grubun dinî ve etnik ideolojileri çerçevesinde elde edilmeye ve genelde Hristiyanlaştırılmaya çalışılmıştır.

Söz konusu müdahalelere dair örneklere 1840’lı yıllardan Millî Mücadele yıllarına kadar geniş bir zaman diliminde rastlamak mümkündür. Bu bağlamda çocuklara yönelik yabancı ve gayrimüslim müdahaleleri bazı yabancı devletlerin de desteğini alan birtakım kişi, grup veya kurumlar aracılığıyla gerçekleştirilmiş, öldürme, kaçırma, sahiplenme, alıkoyma veya barındırma gibi çeşitli şekillerde ortaya çıkmıştır. Öncelikli olarak ele alınacak olan yabancı müdahaleleri, münferiden ya da herhangi bir devlet, sınıf veya grup tarafından planlı bir şekilde yürütülmüştür.

\subsection{Yabancı Müdahaleleri}

Yabancıların münferit müdahalelerine 1844 dolaylarında gerçekleşen ve Yunan tebaasından Nikola ve adamlarının, muhacirlerden Kâmile Hanımın evini basarak eşyalarını ve on iki yaşındaki kız çocuğunu kaçırmaları örnek gösterilebilir. ${ }^{28}$ Müslüman bir ailenin çocuğunun Hristiyan Yunanlılar tarafindan kaçırılması, çocuğa yönelik müdahaleye dair önemli bir örnektir. Osmanlı Devleti'nin Balkanlarda büyük kayıplar yaşamasına yol açan 1877-1878 Osmanlı-Rus Savaşı sırasında en çok sıkıntı çeken ve ölüm oranının en yüksek olduğu kesim yine çocuklar olmuştur. Bu dönemde yaşanan göçler sırasında çok sayıda çocuk ölmüş ya da öksüz ve yetim kalmıştır. Bu suretle kimsesiz ve muhtaç duruma düşen çocuklar bazı Bulgarlar tarafından alıkonulmuşlardır. ${ }^{29}$ Bulgarların Müslüman çocukları ele geçirme ve alıkoyma faaliyetleri her firsatta devam etmiştir. Bu anlamda yine münferit olarak 1914 yılında gerçekleşen bir olayda, ailesi şehit edilmiş olan dokuz yaşındaki Mustafa adında bir çocuk, Konstantin oğlu Gorki isimli

\footnotetext{
${ }^{27}$ Ersin Müezzinoğlu, "I. Dünya Savaşı Esnasında Yetim ve Öksüz Çocukların Himayesi ve Eğitimi: Darüleytamlar", History Studies, C.4, S.1, Mart 2012, s. 400, 401.

${ }^{28}$ BOA, HR.MKT (Hariciye Nezâreti, Mektubî Kalemi), 3/70, H.11.04.1260.

${ }^{29}$ Pelin İskender Kılıç, “Mehmed Esad Safvet Paşa’nın Devair Müfettişliği Sırasında Muhacirler ve Muhacir Çocuklarıyla İlgili Görüşleri ve Bu Konudaki Çalışmaları”, History Studies, C.9, S.3, Eylül 2017, s.116.
} 
bir Bulgar tarafından gasp edilerek Hristiyanlaştırılmıştır. ${ }^{30}$ Selanik muhacirlerinden Halil bin Salih tarafından 1918 dolaylarında verilen bir dilekçede ise Balkan Savaşları sırasında kardeşleri Mehmet ve Osman'ın yakıldığı, küçük kızlarının ise bir Bulgar tarafından alıkonulduğu ifade edilmiştir. Halil bin Salih, alıkonulan kızların bulunmasını ve kendilerine teslim edilmesini talep etmiştir. $^{31}$ Başka bir örnekte ise Drama muhacirlerinden Süleyman oğlu Hasan, amcası Muharrem'in dört ve altı yaşlarındaki Lebibe ve Habibe isimli kızlarının, Drama'da iki Rum tarafından alıkonularak Hristiyanlaştırıldıklarına dair şikâyette bulunmuştur. Süleyman oğlu Hasan, dinleri değiştirilen kız çocuklarının, yine Drama'ya bağlı bir köyde ikamet etmekte olan Hacı Arif Ağa'ya teslim edilmesini istemiştir. ${ }^{32}$ Belirtilen örneklerde görüldüğü üzere zayıf ve aciz duruma düşmüş olan Müslüman ailelerin çocukları bazı kimseler tarafından zorla ve hileyle ele geçirilmeye ve Hristiyanlaştırılmaya çalışılmıştır. Yukarıda belirtilmiş olan ve münferit olarak gerçekleşen olayların yanı sıra yabancılar, kimsesiz ve muhtaç durumdaki Müslüman çocuklara yönelik daha bilinçli ve planlı müdahalelerde de bulunmuşlardır.

Bu noktada zaman zaman bazı Hristiyan din adamları ve Hristiyan dinî kuruluşların da konuya dahil oldukları görülür. 1913 yılı dolaylarında Yüzbaşı Asım Efendi'nin vefat eden eşi Sadberk Hanımdan olan çocukları Dedeağaç Katolik Mektebi'nde tutulmuşlardır. Bu olay Müslüman ailelerin çocuklarının bir şekilde Hristiyan kurumlar tarafından tutulmalarına dair önemli bir örnektir. Asım Efendi, Bulgar Hükümeti'nin çocuklarını teslim etmemesi üzerine Osmanlı makamlarından, çocuklarının İstanbul'a getirilmeleri talebinde bulunmuştur. ${ }^{33}$

Osmanlı topraklarında bulunan bazı yabancı ülke vatandaşları da kimsesiz çocukları elde etmek istemişlerdir. Osmanlı makamlarının engellemeye çalıştığı bu faaliyetlerde misyonerlerin ön plana çıktığı görülür. Misyoner, bir dini yaymayı amaç edinen ancak özelde Hristiyanlığın yayılması için faaliyet gösteren kişileri ifade eder. Misyonerler Osmanlı toprakları başta olmak üzere pek çok İslâm ülkesinde sömürgeci devletlerin kurulu teşkilatlarıyla yakın ilişki içinde olmuşlar ve karşılıklı çıkarlarını gözetmişlerdir. Sömürge yönetimleri, bulundukları yerlerde idarelerini pekiştirmeyi ve yerli halkın inanç ve geleneklerini kendi çıkarları doğrultusunda asimile etmeyi hedeflemişlerdir. Misyonerler ise sömürgeci güçlerin sağladığı ekonomik, askerî ve siyasi destekle faaliyetlerini sürdürme imkânı bulmuşlardır. ${ }^{34}$

19. yüzy1lda İngiltere, Fransa, Rusya, Avusturya, Almanya, İtalya ve Amerika Birleşik Devletleri gibi ülkelerin her biri Katolik, Ortodoks ya da Protestan mezheplerinden birinin koruyuculuğunu üstlenmişlerdir. Osmanlı topraklarında dinlerini ve mezheplerini yayarak nüfuzlarını arttırmaya çalışan bu ülkeler, amaçlarına ulaşabilmek için misyonerlerden yararlanma yoluna gitmişlerdir. Misyonerler, faaliyetlerini okullaşma, siyasal örgütler kurma ve isyanlar çıkarma şeklinde planladıklarından eğitimi en önemli araç olarak görmüşlerdir. ${ }^{35} \mathrm{Bu}$ bakımdan misyonerlerin Anadolu'daki eğitim faaliyetlerinin başlangıcı, İzmir'de 1733 yılında İngiliz tebaası Rumlar tarafından açılan okula kadar götürülebilir. Protestan misyonerlerin,

${ }^{30}$ BOA, DH.KMS (Dahiliye Nezâreti, Kalem-i Mahsûs Müdüriyeti), 16/41, H. 18.08.1332.

${ }^{31}$ BOA, HR.SFR.04 (Hariciye Nezâreti, Sofya Sefareti), 421/10, M. 01.08.1918.

${ }^{32}$ BOA, HR.SFR 04, 491/29, Lef 5, M.26.05.1917.

${ }^{33}$ BOA, HR.SYS (Hariciye Nezâreti, Siyasi Kalemi), 2029/1, Lef 23, M.29.01.1913.

${ }^{34}$ Şinasi Gündüz, "Misyonerlik" Türkiye Diyanet Vakfi İslâm Ansiklopedisi, C.30, İstanbul 2005, s.197.

35 İsmail Özçelik, Ermeni Sorunu ve Gerçekler, Gündüz Eğitim ve Yayıncılık, Ankara 2005, s.97. 
Osmanlı topraklarındaki ilk kapsamlı misyonerlik faaliyetlerinin ise 1800 yılı dolaylarında Ingiliz Church Missionary Society isimli misyoner kuruluşla başladığı görülür. Misyonerler, Osmanlı topraklarında yalnız Müslüman kesime değil Yahudi, Ermeni, Rum, Nesturi ve Süryani gibi çeşitli din ve mezheplere mensup Osmanlı tebaasına yönelik de bölücü ve kışkırtıcı faaliyetler yürütmüşlerdir. Bu faaliyetlerinde onlara başta İngiliz Sefareti olmak üzere yabancı ülke temsilcilikleri yardımcı olmuştur. Misyonerler, faaliyetlerinin temelini teşkil etmesi açısından çok sayıda okul, yetimhane ve hayrathane açmışlardır. 1881 ve 1886 yıllarında Antakya'da açılan iki okulla Maraş'ta bir yetimhane ve Friend Society adlı misyoner kurum tarafından kimsesiz kız çocukları için açılan Ingiliz Hayrathanesi bunlardan yalnızca bir kaçıdır. ${ }^{36}$ Ancak Misyonerlerin kimsesiz çocuklara yönelik faaliyetleri, çocukların bakımı veya eğitiminden ziyade onların siyasi, dinî ve ideolojik açıdan etki altına alınmaları amacını taşımıştır.

İngiliz misyonerlerin, Suriye'nin Kerek Kasabası'ndaki Müslüman çocuklar arasında Hristiyanlık propagandası yapmalarına karşılık Osmanlı makamları, mahalli ulemadan bir kişiyi görevlendirerek misyonerlerin etkilemeye çalıştığı çocukları İslâm dini konusunda bilgilendirmeye ve bu yolla İngilizleri engellemeye çalışmıştır. ${ }^{37}$ Osmanlı Devleti, izin ve ruhsat alınmaksızın açılan ve faaliyet gösteren misyoner okullarının faaliyetlerini durdurmak ve bu okullara Müslüman çocukların devam etmelerini önlemek istemiştir. ${ }^{38}$ Buna karşılık misyonerler, İngiliz misyoner Barker'in ruhsatsız olan okuluna İngiliz bayrağı çekmek suretiyle İngiliz himayesine sığınması örneğinde olduğu gibi, vatandaşı bulundukları yabanc1 devletlerin himayesine güvenerek Osmanlı makamlarının müdahalesini engellemeye çalışmışlardır. ${ }^{39}$ Ayrıca kendi devletlerinin nüfuz ve himayesine güvenen misyonerler, faaliyetlerinde Osmanlı Devleti kanunlarını ve Osmanlı makamlarını yok sayarak sefaretlerinin emirlerini dikkate almışlardır. Örneğin Alman uyruklu Baht adında bir misyoner, yasak olmasına rağmen topladığı kimsesiz ve muhtaç çocukları devlete iade etmeyerek bu konuda sefaretinden gelecek emri beklemeyi tercih etmiştir. ${ }^{40}$

Osmanlı topraklarında misyonerlik faaliyetleri yürüten ve bu yolla kimsesiz çocuklara yönelik müdahalelerde bulunan gruplardan biri de Amerikalı misyonerlerdir. Amerika'da Kongregasyoneller öncülüğünde 19. yüzyılda kurulan American Board of Commissioner of Foreign Mission'a bağlı misyonerler Suriye, Filistin, İran, Irak, Mısır, Ürdün ve Anadolu'da faaliyette bulunmuşlardır. ${ }^{41}$ Amerikan Board okulları Osmanlı azınlıkları üzerinde büyük bir etkiye sahip olmuş ve bu etki artarak devam etmiştir. İlk başlarda Amerikan misyonerleri, yürütülen faaliyetlerle azınlıklara dinî, sosyal ve kültürel alanlarda yeni bir hayat görüşü

\footnotetext{
${ }^{36}$ Bengül Polat-Ratip Ayvaz, "İngiliz Misyonerlik Faaliyetlerinin Osmanlı Devleti’nin Yıkılış Sürecine Etkileri”, Atatürk Yolu Dergisi, Ankara Üniversitesi Türk İnkılap Tarihi Enstitüsü, S. 61, Güz 2017, s. 4, $6,11$.

${ }^{37}$ Polat-Ayvaz, "agm”, s. 13.

${ }^{38}$ BOA, Y.EE. KP (Yıldız, Esas Kâmil Paşa Evrakı), 8/798, H. 28.08.1316.

${ }^{39}$ Polat-Ayvaz, "agm”, s. 12.

${ }^{40}$ BOA, DH. ŞFR (Dahiliye Nezâreti, Şifre Kalemi), 236/16, R. 05.03.1315.

${ }^{41}$ Gündüz, "agm”, s. 197.
} 
kazandırmaya çalışmışlardır. ${ }^{42}$ Bunun yanı sıra bazı Amerikalı misyonerlerin, 1902 yılında Bitlis ve civarında olduğu gibi fakir Ermeni çocukların fotoğraflarını kullanmak suretiyle onlara ekonomik yardımlar sağlama girişimleri de olmuştur. ${ }^{43}$ Fakat son aşamada, gerçekleştirilen tüm eğitim faaliyetlerine ve elde edilen yeterliliklere siyasi bir kimlik kazandırılmaya çalışılmıştır. Böylece Osmanlı bünyesindeki azınlıklar, misyonerler tarafından kendi devletlerinin amaçları doğrultusunda Osmanlı Devleti ile karşı karşıya getirilmiştir. ${ }^{44}$

Amerikan Protestan misyonerlerinin hedef kitlesi genelde Ermeniler olmuştur. Bu yüzden onların açtıkları okullardan en fazla yararlananlar da Ermenilerdir. Örneğin 1878 yılında Harput'ta açılan okulun eğitim dili Ermenice olduğu gibi ismi de Ermenistan Koleji idi. Bu isme Babıâli'nin itiraz etmesi üzerine okulun ismi Firat Koleji olarak değiştirilmiştir. Fakat Amerikalı misyonerler yalnız Ermeni çocukları hedef almamışlar ve söz konusu okulların gayrimüslim çocukların yanı sıra Müslüman çocuklara da hitap ettiğini gizleyememişlerdir. Hatta bu nedenle ruhsat alamayacaklarını bildikleri için okullardan bazıları ruhsatsız faaliyette bulunmuştur. ${ }^{45}$ Amerikalı misyonerler, çeşitli yollarla topladıkları Müslüman ve gayrimüslim çocukların söz konusu okullarda iyi bir Hristiyan ve Ermeni milliyetçisi olarak yetişmelerini ve Osmanlı toplumuna geri dönmelerini amaçlamışlardır. Hatta zeki olan çocukların Avrupa ve Amerika Birleşik Devletleri'ne gönderilerek buralarda ileri derecede eğitim almaları sağlanmıştır. ${ }^{46} \mathrm{Bu}$ nedenle Osmanlı Devleti'nde pek çok gayrimüslim veya Müslüman kimsesiz çocuğun yurt dışına kaçırılma olayları ortaya çıkmıştır. Osmanlı Devleti, Diyarbakır örneğinde olduğu üzere misyonerlerin gizlice çocuk topladıklarını ve okullar açtıklarını hatırlatarak ilgili makamlardan bunun önlenmesini istemiştir. ${ }^{47}$ Ancak Amerikalı misyonerler çok sayıda çocuğun yurt dışına kaçırılmasına aracılık etmişlerdir. Örneğin Midyat'ta on iki yaşında Müslüman bir çocuğun Protestan misyonerlerce Amerika'ya kaçırılması, ${ }^{48}$ Adana ve Mersin dolaylarında faaliyet gösteren Doktor Martin/Matin adlı misyonerin Nusayri taifesinden üç kızı Amerika'ya kaçırması ${ }^{49}$ Samuel Zivimer isimli bir misyonerin elli kadar çocuğu Amerika'ya kaçırması ve Diyarbakır'da da Müslüman bir çocuğun Hristiyanlaştırılarak Amerika'ya gönderilmesi, Amerikalı misyonerlerin karıştıkları olaylardan yalnızca bir kaçıdır. ${ }^{50}$ Verilen örneklerde görüldüğü üzere misyonerler, çocukları elde etmek için kanun dışı yollara başvurmaktan çekinmemişlerdir.

\footnotetext{
${ }^{42}$ Gülbadi Alan, “Amerikan Board Okullarında Yürütülen Misyonerlik Faaliyetleri”, İslâmî Araştırmalar Dergisi, C. 20, S.4, Y11 2007, s.469.

${ }^{43}$ BOA, HR.TH, 271/58, (Hariciye Nezâreti, Tahrirât-ı Hariciye Odası), M. 21.07.1902.

${ }^{44}$ Alan, "agm", s.469.

${ }^{45}$ Emine Dingeç, “Amerikan Misyoner Okullarının Ermeni Ayrılıkçı Hareketlerindeki Yeri”, Hoşgörüden Yol Ayrımına Ermeniler, C.2, Erciyes Üniversitesi Yayını, Kayseri 2009, s. 34,35,36.

${ }^{46}$ Bayram Akça, "Antep (Ayıntap) Protestan Okulu ve Ermeni Meselesi”, Ermeni Araştırmaları, YazSonbahar 2004, C.4, S.14-15, Avrasya Stratejik Araştırmalar Merkezi Yayınları, Ankara 1994, s. 46.

${ }^{47}$ BOA, Y.PRK.UM (Ylldız, Perakende, Umum Vilayetler), 46/29, H.10.01.1317; BOA, Y.PRK. UM. 46/ 64, H. 29.01.1317.

${ }^{48}$ BOA, Y.PRK.UM, 20/112, H.07.07.1308.

${ }^{49}$ BOA, MF.MKT (Maârif Nezâreti, Mektubi Kalemi), 203/30, Lef 5, H.22.10.1311.

${ }^{50}$ BOA, HR.SYS, 71/32, M.24.03.1891.
} 
Amerikan misyoner okullarında gerek Müslüman gerekse gayrimüslim çocukların beyinlerinin yıkanarak yıkıcı ve bölücü fikirlerle kandırılmalarından dolayı Osmanlı Devleti, özellikle Müslüman çocukların bu tür okullara gitmelerini önlemeye çalışmıştır. Ayrıca gayrimüslim yerli halkın bile zaman zaman Amerikalı misyonerlerin faaliyetlerinden şikâyetçi oldukları görülür. ${ }^{51}$ Osmanlı makamları bu noktada daha sıkı önlemler almaya çalışmıştır. Bu bağlamda İskân-1 Aşayir ve Muhacirîn Müdüriyeti tarafından Kayseri Mutasarrıflığına çekilen telgrafla, yetim çocukların Amerikalı misyonerlerin nazarlarından uzak tutulmaları istenmiştir. ${ }^{52}$ Hatta Osmanlı Devleti, misyonerlik faaliyetlerinde 1srar eden bazı kimseleri tutuklama yoluna bile gitmiştir. Karataş Nahiyesinde Müslüman ve gayrimüslim çocuklara Hristiyanlık aşılamaya ve öğretmeye devam eden David isimli misyoner buna örnek olarak gösterilebilir. ${ }^{53}$ Kimsesiz çocuklara müdahale eden yabancı misyonerlerin Osmanlı topraklarından sınır dışı edildikleri de olmuştur. Bu bağlamda Van'da yaşayan İngiliz Misyoner Mister Brovn, Nesturi çocukların mezheplerini değiştirdiği gerekçesiyle Osmanlı topraklarından çıkarılmıştır. ${ }^{54}$

Osmanlı Devleti'nin, kimsesiz ve muhtaç çocukları yabancı misyonerlerin etkisinden korumada takip ettiği tek yol çocukların misyonerlere ait eğitim kurumlarına gitmelerini önlemek ya da misyonerleri sınır dişı etmek olmamıştır. Karşı tedbir olarak çocukların eğitim alabilecekleri yeni devlet kurumları oluşturulmaya çalışılmıştır. Örneğin Cedide Kazasında Müslüman çocukların Katolik ve Amerikalı Protestan misyonerlerin açtıkları okullara gitmelerini önlemek amacıyla yeni bir okul ve cami yaptırma yoluna gidilmiştir. ${ }^{55}$ Yine Adana, Mersin ve Tarsus dolaylarında muzır yani zararlı faaliyetlerde bulunan Dr. Martin isimli Amerikalı misyonerin faaliyetlerini önlemek için de rüştiye düzeyinde kız okulları açılması yoluna gidilmiştir. ${ }^{56}$ Ayrıca Osmanlı Devleti, talep olması halinde her seviyede eğitim kurumunda fakir ve kimsesiz çocukların karşılıksız olarak eğitim görebilmeleri noktasında gayret göstermiştir. ${ }^{57}$ Bu tür çabaların, yetenekli olmakla birlikte fakirlik ve kimsesizliğinden dolayı tahsil göremeyen bu yüzden yabancıların ve gayrimüslim azınlıkların eline düşme tehlikesi bulunan çocukların korunmasında payı vardır. Bunun yanı sıra Osmanlı Devleti’nin, Müslüman tebaaya ve kimsesiz çocuklara yönelik yabancı ve gayrimüslim müdahalesini azaltmak veya önlemek amacıyla bazı bölgelerde Müslüman nüfusu arttırmaya çalıştığı da görülür. Örneğin Ermeni nüfusun yoğun olarak yaşadığ 1 Cebel-i Bereket Sancağı, başta Cizvit papazları olmak üzere Protestan ve Lazaristlerin faaliyet alanı haline gelmiştir. Osmanlı Devleti bunların faaliyetlerini takip etmeye ve kontrol altında tutmaya çalışmıştır. Bu gruplar daha da ileri giderek yabancı devletlerin de desteğiyle bölgede arazi satın almaya ve buralara Ermenileri ve diğer gayrimüslimleri yerleştirmeye çalışmışlardır. Bölgede Müslüman nüfusun azınlık durumuna düşmesine ve çeşitli sorunların ortaya çıkmasına yol açabilecek olan bu faaliyetler Osmanlı Devleti tarafından

${ }^{51}$ BOA, DH.TMIK.M (Dahiliye Nezâreti, Tesrî-i Muamelat ve Islahat Komisyonu Muamelat), 168/ 7, H. 29.01.1322; BOA, HR.SFR.1 (Hariciye Nezâreti, Petersburg Sefareti), 181/129, M.28.11.1895.

52 BOA, DH.ŞFR, 63/276, H.08.071334.

${ }^{53}$ BOA, DH.MKT, 1517/56, H. 20.10.1305.

${ }^{54}$ BOA, DH.TMIK.M, 242/22, H. 16.03.1325.

${ }^{55}$ BOA, Y.MTV (Ylldız, Mütenevvi Maruzât Evrakı), 185/80, H. 21.08.1316.

${ }^{56}$ BOA, MF.MKT, 195/10, H. 30.07.1311.

57 Hakan Türkkan, “Osmanlı Devleti'nde Muhtaç ve Kimsesiz Çocukların Karşılıksız Eğitimi”, VI. Uluslararası Tarih Eğitimi Sempozyumu, Bolu, 10-12 Ekim 2019, s.477. 
önlenmeye çalışılmıştır. Bu amaca yönelik olarak Osmanlı makamları, başta Müslüman muhacirler olmak üzere bölgeye Müslüman nüfus iskân edilmesi yoluna gitmiştir. ${ }^{58}$

Savaş ve göç dönemlerinde Osmanlı topraklarındaki kimsesiz ve muhtaç çocukların sayısında artışlar olmuştur. $\mathrm{Bu}$ durum misyonerlerin söz konusu çocukların barınma ve beslenme ihtiyaçlarını karşılama bahanesiyle faaliyette bulunmalarının önünü açmıştır. $\mathrm{Bu}$ anlamda örneğin Kayseri'de Protestanlar, okul faaliyetlerinin yanı sira yetimhane faaliyetlerine de girişmişler ${ }^{59}$ ve kimsesiz çocukları kendi kontrollerindeki yetimhanelerde tutmuşlardır. Ancak Osmanlı makamları her fırsatta bu tür faaliyetleri engellemeye çalışmıştır. Örneğin Kayseri'de Amerikalı misyonerlerin idaresindeki bir yetimhanenin hastaneye çevrilerek çocukların vilayet yetimhanelerine gönderilmesi, misyonerlerin kimsesiz çocuklara müdahalesini önlemeye yönelik doğrudan atılmış bir adımdır. ${ }^{60}$ Yine Alman ve Amerikalı misyonerlerin kontrolünde Palu'da izinsiz faaliyet gösteren darütterbiyede bulunan çocuklar da devlet tarafindan ailelerine teslim edilmiştir. ${ }^{61}$

\subsection{Gayrimüslim Azınlıkların Müdahaleleri}

Yabancılar dışında Osmanlı tebaasından olan gayrimüslim azınlıklar da kimsesiz çocuklara yönelik müdahalelerde bulunmuşlardır. Gayrimüslimlerin kimsesiz çocuklar üzerinde yürüttükleri faaliyetlerin büyük ölçüde milliyetçi fikirlerden beslendiği görülür. 19. yüzyılda milliyetçilik duygusu Osmanlı Hristiyanları arasında yayıldıkça Osmanlı azınlıklarının milliyetçiliği giderek daha ırkçı bir karakter kazanmıştır. Bununla birlikte milliyetçilik ve din bağı zayıflamamış, Rum, Bulgar ve Ermeni gibi Osmanlı azınlıklarının millî bilinçleri dinî kimlikleriyle şekillenmiştir. Azınlıkların milliyetçiliklerindeki dinî öğeler, amaçlarının belirginleşmesine ve taviz kabul etmez bir şekilde şiddetlenmesine yol açmıştır. Bu bakımdan azınlıklar amaçlarını meşrulaştırırken, düşman kabul ettikleri Müslümanların yalnız millî hedefleri için değil dinî inançları için de tehdit olduklarını düşünmüşlerdir. $\mathrm{Bu}$ durum Müslümanları ortak hedef haline getirmiş ve Müslümanlar sırf dinlerinden dolayı her milliyetçi grup tarafindan ulusal düşman olarak görülmüşlerdir. ${ }^{62}$ Bu nedenle Kafkasya örneğinde olduğu gibi işgal edilen Müslüman ülkelerde aileler zorla ve baskıyla, çocuklar ise eğitim yoluyla Hristiyanlaştırılmaya çalışılmıştır. Hristiyanlığ 1 kabul etmeyenler ise katledilmiş ya da sürülmüşlerdir. ${ }^{63} \mathrm{Bu}$ bağlamda Osmanlı Devleti'nde din değiştirmeyle ilgili sorunlar da milliyetçi hareketlerle sıkı sıkıya ilintili olmuştur. Giderek güçlenen dinî hamaset ve ihtiraslar, ihtida ve irtidad yoluyla milliyetçiliğin boyunduruğu altına girmiştir. 19. yüzylla kadar bir gayrimüslimin Müslüman olması, arzu edilmeyen ve gerek papazlar gerekse söz konusu cemaat üyeleri tarafından kötü gözle bakılan bir davranış olarak görülmüş ancak büyük sorunlara neden

${ }^{58}$ Burak Kocaoğlu, "Bir İskân Bölgesi Cebel-i Bereket Sancağı ve Yaşanan Sorunlar”, Türkiye'nin Bölgesel Sorunlarl "Osmanlı'dan Günümüze” Ortadoğu, Edt. Mehmet Çelik-Alev Duran, Hiperlink Yayınları, İstanbul 2020, s.260-261.

${ }^{59}$ BOA, DH.ŞFR, 390/28, R. 14.09.1323.

${ }^{60}$ BOA, DH.ŞFR, 518/23, R.16.02.1332.

${ }^{61}$ BOA, DH.ŞFR, 231/76, R. 21.11.1314.

${ }^{62}$ Justin McCarthy, Ölüm ve Sürgün Osmanlı Müslümanlarının Etnik Klyımı 1821-1922, Çev. Fatma Sarıkaya, Türk Tarih Kurumu Yayınları, Ankara 2014, s.7-8.

${ }^{63}$ Nedim İpek, Imparatorluktan Ulus Devlete Göçler, Serander Yayınları, Trabzon 2006, s. 32. 
olmamıştır. Buna karşılık 19. yüzyılda dinî ve millî kimlik arasında öylesine sıkı bir bağ oluşmuştur ki bir kimsenin ihtida etmesi yani Müslüman olması bir kimlik yitimi ve korkunç bir kayıp görülmeye başlamıştır. Bu yüzden Hristiyanlar açısından ihtida, bütün cemaat ya da milletin iç dünyasının ihlali, aşağılanması, ona tehdit ve hakaret edilmesi olarak algılanmıştır. Bu bakımdan herhangi bir köylünün Müslümanlığı seçmesi gibi sıradan bir olay bile 19. yüzyılda uluslararası bir soruna dönüşebilmiştir. Din değiştirmeye karşı ortaya çıkan bu tutum nedeniyle kadın ve çocukların ihtidaları da bu dönemde hassas bir mesele haline gelmiştir. Çünkü ihtida eden kişinin kadın ya da çocuk olması, cemaatin namusunun simgesel olarak kirlenmesi şeklinde düşünülmüştür. ${ }^{64}$ Sözü edilen anlayış, gayrimüslimlerin kimsesiz çocukları hile ve zorla elde ederek kendi dinlerine kazanma konusunda eskisine nazaran çok daha hırslı olmalarına neden olmuştur. Bu da kimsesiz ve muhtaç durumdaki çocukların dinlerine ve yaşamlarına yönelik çeşitli müdahaleleri doğurmuştur.

Özellikle Hristiyan Ermeni ve Rum azınlıklar tarafından gerçekleştirilen bu müdahaleler sırasında bazı yabancı devletlerin temsilci ya da misyonerleri, azınlıkların koruyucusu ve destekçisi olmuşlardır. Misyoner okulları, başta Ermeniler olmak üzere gayrimüslim azınlığın Osmanlı Devleti'ne yönelik isyan faaliyetlerini desteklemişlerdir. Misyonerler ve yabancı devletlerin Osmanlı topraklarındaki birtakım görevlileri, azınlık isyanlarının teorisinin hazırlanması, eylemcilerin yetiştirilmesi ve korunması görevini üstlenmiştir. ${ }^{65} \mathrm{Bu}$ nedenle gayrimüslim müdahaleleri yabancı müdahalelerinden ayrı düşünülemez.

Azınlıklar, sözü edilen yabancı desteğine de güvenerek gerek kişisel gerekse kurumsal olarak kimsesiz çocukların Hristiyanlaştırılması amacıyla her firsatı değerlendirmişlerdir. Örneğin 1860'lı yıllarda Osmanlı makamlarının bütün engellemelerine rağmen bazı gayrimüslimler ve birtakım yabancılar, Trabzon' da çocuklarını satmak zorunda kalan ya da bunu alışkanlık haline getiren Çerkez muhacirlerden çocuk satın almışlardır. Başka bir ifadeyle çocuklar üzerinden esir ticareti yapmışlardır. ${ }^{66}$ Gayrimüslimlerin ve yabancıların söz konusu çocukları satın almaktaki maksatlarının onları köleleştirmek ve dinlerini değiştirmek olduğu açıktır. Başka bir örnekte ise Keşan'da Müslüman bir muhacir kadın gayri meşru olarak dünyaya getirdiği erkek çocuğunu Rum mahallesi civarına terk etmiş ve bu çocuk metropolithane tarafından alınarak Hristiyan bir aileye verilmiştir. Dolayısıyla bu davranışta da bir şekilde elde edilen çocuğa samimi bir yardımdan ziyade onun Hristiyanlaştırması amacı güdüldügü görülmektedir. ${ }^{67}$

Kimsesiz çocuklara yönelik müdahalelerde Ermenilerin son derece aktif oldukları görülür. Birinci Dünya Savaşı yıllarında şiddetli ve acımasız faaliyetlerde bulunan Ermeniler, 1915 başlarında yalnızca Doğu Anadolu bölgesinde 102 binden fazla Müslümanı katletmişlerdir. Daha da önemlisi bu dönemde Ermeniler, köylere kadar ulaştırdıkları talimatla, iki yaşına kadar olan bütün Müslümanların görüldükleri her yerde ve her firsatta öldürülmeleri emrini vermişlerdir. $\mathrm{Bu}$ bilgiden de anlaşılacağı üzere Ermeniler planlı bir biçimde Müslümanları katletmişler ve

${ }^{64}$ Selim Deringil, 19. Yüzyll Osmanlı Devleti'nde İhtida ve Irtidad, Çev. Ayşen Anadol-Taciser Ulaş Belge, İletişim Yayınları, İstanbul 2017, s.24-26.

${ }^{65}$ Özçelik, age, s.96.

${ }^{66}$ BOA, A.\} MKT.UM, 789/39, H.12.02.1281.

${ }^{67}$ BOA, DH.MKT (Dahiliye Nezâreti, Mektubî Kalemi), 1007/53, H.19.07.1323. 
katliamlarda çocukları bilinçli ve kasıtlı olarak hedef almışlardır. ${ }^{68}$ Ermenilerin Müslümanlara yönelik eylemleri 1915 yılında Osmanlı Devleti'nin tehcir kararı alması sonucunu doğurmuştur. Tehcir sırasında kimsesiz Ermeni çocukların ortaya çıkması, henüz 1900'lü yıllarda bile darütterbiyelerde eğitmek için Ermeni kökenli çocukları toplayan ve onları din ve mezhep değiştirmeye meyilli gören misyonerlerin iştahını kabartmıştır. Osmanlı makamları, misyonerlerin kimsesiz Ermeni çocuklarını toplamalarına göz yumulmasının, Müslüman çocukları toplamalarında onlara kolaylık sağlayacağından da endişe duymuşlardır. Bu yüzden misyonerlerin bu faaliyetlerini önlemeye çalışmışlar fakat karşılarında yabancı devletlerin temsilcilerini bulmuşlardır. ${ }^{69}$

Özellikle Birinci Dünya Savaşı yılları ve Mondros Mütarekesi döneminde Ermeni toplumunun ya da onlar adına hareket eden yabancı unsurların kimsesiz ve muhtaç durumdaki Müslüman çocukları sahiplenmeye çalıştıkları görülür. Buna karşılık Osmanlı Devleti, sevke tabi tutulmayan ve kimsesiz duruma düşen Ermeni çocukları korumaya ve onların Ermeni ve yabancıların kontrolünde kalmalarını önlemeye çalışmıştır. Bu maksatla kimsesiz Müslüman ve muhacir çocuklar örneğinde olduğu gibi Ermeni çocukların da Ermenilerin bulunmadığı köy ve kasabalara dağıtılmaları veya darüleytam ve öksüz yurtlarına yerleştirilmeleri yoluna gidilmiştir. Darüleytamların yetersiz kalması durumunda ise çocukların sahib-i hal Müslümanların yanına verilmeleri istenmiştir. Sahibi hal Müslüman aile bulunamadığı takdirde muhacirîn tahsisatından 30 kuruş iaşe masrafı verilerek köylülere dağıtılmalarına karar verilmiştir. ${ }^{70} \mathrm{Bu}$ dönemde Osmanlı kanunlarına göre ihtidaların kabul yaşının on beş olması ve Hükümetin tehcir nedeniyle asgari ihtida yaşını yirmiye çıkarması, Ermeni çocuklarına yönelik herhangi bir İslamlaştırma gayreti olmadığını ortaya koymaktadır. ${ }^{71}$ Buna karşılık misyonerler ve onların desteğini alan başta Ermeniler olmak üzere gayrimüslim Osmanlı tebaası, kimsesiz ve muhtaç durumdaki çocukların himayeleri bahanesiyle onların dinlerini değiştirmeye çalışmışlardır. Bunun için en uygun yer yetimhaneler olduğundan bazı yetimhaneler yabancı ve Ermeni tebaasından kimseler elinde kalmıştır. Halep’te bulunan üç adet darüleytamdan birincisi Alman misyoner Rosner tarafından, ikincisi Protestan Ermenilerinden Aron Şıraciyan tarafından, üçüncüsü ise Ermeni Kireççiyan tarafindan himaye ve idare edilmiştir. Söz konusu yetimhanelerde toplamda 1002 erkek ve 484 kız olmak üzere yaklaşık1500 civarında kimsesiz çocuk, yabancı ve Ermenilerin himaye ve idaresinde kalmıştır. ${ }^{72}$ Osmanlı Devleti, kimsesiz çocukları gerek yeni darüleytamlar oluşturmak gerekse mevcut devlet darüleytamlarına dağıtmak suretiyle yabancı ve Ermenilerden kurtarmaya çalışmıştır.

Ancak çocukların iaşe ve bakımlarının uzun süre sağlanamayacağı düşüncesi gayrimüslim çocukların ailelerine, akrabalarına veya mensup oldukları cemaatlerin ruhani reisleriyle

${ }^{68}$ Selma Göktürk Çetinkaya, "Tehcir Sonrası Müslüman Çocuklara El Konulması Meselesi”, Tarih Dergisi, S.65, İstanbul 2017/1, s.133-134.

${ }^{69}$ BOA, DH.TMIK.M, 69/58, Lef 7, H.26, 12.1316.

${ }^{70}$ BOA, DH.ŞFR, 63/142, H.26.06.1334; Süleyman Beyoğlu, "Ermeni Tehciri ve İhtida", Yakın Dönem Türkiye Araştırmaları, S.6, 2004, s.4-5.

${ }^{71}$ Beyoğlu, "agm", s.3.

${ }^{72}$ BOA, MF.MKT, 1221/81, H.28.02.1335. 
görüşülerek onlara teslim edilmesi ihtiyacını doğurmuştur. ${ }^{73}$ Buna bağlı olarak 1918 baharından itibaren tehcir edilen Ermenilerin geri dönmeleri yönünde çalışmalar başlamıştır. Ayrıca geri dönen Ermenilerin çocuklarını alabilmelerine yönelik kararlar da kısa sürede uygulamaya konulmuştur. ${ }^{74}$ İade sürecinde Osmanlı Devleti, Müslüman aileler yanında kalan Ermeni çocuklarının bir kısmına talep olmamasına rağmen onların da ailelerden alınarak yetimhanelere gönderilmesini istemiştir. Çocukların pek çoğu alıştıkları ailelerden ayrılmak istememişlerdir. Buna rağmen arzularına bakılmaksızın yetimhanelere teslim edilmeleri emredilmiştir. Bu kararla, Ermeni çocukların Müslüman aileler yanında zorla alıkonulduğu gibi bir suçlamanın önüne geçilmeye çalışıldığ anlaşılmaktadır. $^{75}$

Osmanlı Devleti'nin bu kararına karşl1ık, kargaşa ortamından yararlanan Ermeniler başta olmak üzere gayrimüslim cemaat ve misyoner teşkilatları, yabancı devletleri de arkalarına alarak Müslüman çocukları zorla ve hileyle ele geçirmeye kalkmışlardır. Öyle ki Türk aileler bu dönemde çocuklarının her an ellerinden alınacağı endişesine kapılmışlardır. Mütareke döneminde gayrimüslim çocukların Osmanlı Devleti tarafından ailelerine ve cemaat reislerine teslim edilmesi sırasında Ermeniler, Müslüman ailelerin çocuklarını da gayrimüslim oldukları gerekçesiyle talep etmişlerdir. ${ }^{76}$ Yine Mütareke döneminde Darüleytam Müdüriyetinin emriyle Kayseri Darüleytamından İstanbul'a gönderilen yaklaşık iki yüz kimsesiz Türk çocuğunu Ermeniler zorla ve hileyle ele geçirmeye çalışmışlardır. Bu amaçla Haydarpaşa'da yaygara çıkararak söz konusu çocukların Hristiyan olduklarını iddia etmişler ve çocukları Patrikhaneye teslim etmişlerdir. Millî Mücadele yıllarında Kayseri Himaye-i Etfal Cemiyeti, Refet Paşa'ya başvurarak söz konusu çocukların kurtarılması talebinde bulunmuştur. ${ }^{77}$ Ayrıca Ermeniler, 1919 yılında bazı Müslüman ailelerin kızlarını da Hristiyan oldukları iddiasıyla evlerinden almışlar ve bu kızlardan bir kısmı Müslüman olduklarının ispat edilmesiyle iade edilmişlerdir. ${ }^{78}$ İade edilmeyenler ise Ermeni yetimhanelerine gönderilmiş ya da Ermenilere evlâtlik olarak verilmiştir. $^{79}$

Müslüman çocukların gayrimüslim oldukları zan ya da iddiasıyla elde edilmeye çalışılmasında Ermenilerin tek başlarına hareket etmedikleri görülür. Bu konuda Ermenilere yalnız yabancı temsilci veya misyonerler değil işgalci İtilaf Devletleri de bizzat yardım etmişlerdir. Bu konuda Ermenilere en önemli katkıyı Fransa ve İngiltere yapmıştır. Mondros Mütarekesi döneminde İstanbul'da bulunan İtilaf Devletleri temsilcilerinin ilk işi Ermeni çocukların Müslüman aileler yanında zorla tutulduğu ve dinlerinin değiştirildiği iddiasını ele almak olmuştur. Bu iddiaları araştırmakta olan İtilaf Devletleri hizmetinde Ermeni zabita memurlarının bulunması, Müslüman çocuklar açısından büyük tehlike arz etmiştir. Bu dönemde İngiltere Elçiliğinde Ermeni-Rum şubesi açılmış ve Yüksek Komiser Muavini General Deeds,

${ }^{73}$ BOA, DH.ŞFR, 97/104, H.08.06.1337.

${ }^{74}$ Çetinkaya, "agm", s. 144.

75 Bülent Bakar, "Mondros Mütarekesi'nden Sonra Yaşanan Önemli Bir Problem: Türk ve Ermeni Yetimleri Sorunu”, Atatürk Araştırma Merkezi Dergisi, C.21, S.62, Y11 2005, s. 574, 575-576.

76 BOA, DH.ŞFR, 96/248, H.19.05.1337.

${ }^{77}$ BOA, HR.İM (Hariciye Nezareti İstanbul Murahhaslı̆̆l), 59/50, Lef 2, M.02.01.1922.

${ }^{78}$ Bakar, "agm", s.576.

79 Geniş bilgi için Bk. Ferhunde Özbay, "1911-1922 Yıllarında Anadolu’nun Kimsesiz Kız Çocukları", Savaş Çocuklarl, Öksüzler ve Yetimler, Edt. Emine Gürsoy Naskali-Aylin Koç, İstanbul 2003, s.105-118. 
gazetelerin Ermeni faaliyetleri konusunda yazı yazmalarını tehditle engellemiştir. Gayrimüslim Ermeni ve Rumların Müslümanlara karşı kışkırtıldıkları ve şımartıldıkları böyle bir ortamda Ermeni ve Rumlar kimsesiz Müslüman çocukları hatta nüfuzlu Müslüman ailelerin çocuklarını zorla alma yoluna gitmişlerdir. Yarbay Muhittin Bey ve eşinin evlat edindikleri ve annesi babası Türk olan çocukları da Ermenilerin eline geçmiştir. Ermeni ihtilalciler söz konusu çocuğun Ermeni olduğunu iddia ederek ailesinden zorla almışlar ve Ermeni Papazların idare ettiği bir kampa teslim etmişlerdir. ${ }^{80} 1919$ dolaylarında da İtilaf Devletleri tarafından Konya Öksüz Yurdu talebesi olan İsmail isimli bir çocuk, Ermeni olduğu iddia edilerek İngilizler tarafından alınmış ve İstanbul'a sevk edilmiş ancak daha sonra çocuğun Müslüman olduğu anlaşılmıştır. ${ }^{81}$ Çok sayıda örneği olan bu olaylar sırasında Ermeniler bizzat İşgal Orduları Komutanlığı tarafından destek ve himaye görmüşlerdir. Bu sayede diledikleri her şeye el koyabildikleri gibi Müslüman ya da Ermeni olup olmadığına bakılmaksızın sokaklardan ve evlerden 1300'den fazla çocuğu ele geçirmiş ve Patrikhaneye teslim etmişlerdir. ${ }^{82}$ Ermeni ve Rumların İtilaf Devletlerinin himayesi altında gerçekleştirdikleri bu hadiseler karşısında İtilaf zabıtası sessiz kalmış ve işlerine karışılmamasını emretmiştir. Bu yüzden dönemin Osmanlı Hükümeti resmi olarak bir tepki gösterememiş ve engelleme faaliyetinde bulunamamıştır. ${ }^{83}$

\section{Sonuç}

Zayıf ve aciz bireyler olan çocuklar toplumda kendisini koruyacak ve ifade edecek güçten yoksundur. $\mathrm{Bu}$ durum çocuğun bazı dönemlerde maddi ve manevi eziyet görmesi hatta katledilmesi gibi sonuçları doğurabilmiştir. İslâm inanç ve anlayışı, çocuğa yönelik en katı ve haksız uygulamaların yapıldığı bir dönemi sonlandırmış bu itibarla çocuğun korunması ve gözetilmesine büyük önem vermiştir. Osmanlı devlet ve toplum hayatında da çocuk konusunda İslâm inanç ve anlayışı çerçevesinde oluşan tecrübelerden yararlanılmış ve çocuğun haklarının korunması yönünde hassas davranılmıştır. Bu açıdan Osmanlı toplumunda çocukların korunması noktasında aile birinci derecede sorumlu tutulmuş, ailesi olmadığı takdirde yakın akrabaları, akrabalarının da olmaması durumunda toplum olarak çocuğa sahip çıkılması anlayışı yerleşmiştir. Bu noktada işlevini kaybedinceye kadar vakıflar da çocukların himayesi konusunda önemli rol oynamıştır. Ancak vakıfların özelliğini yitirmesiyle çocuklar kendilerini koruyacak bir kurumun himayesinden mahrum kalmıştır. Bu nedenle Osmanlı Devleti'nde çocukların himayesi ve korunması görevini yerine getirecek ıslahhane ve yetimhane türünden kurumların oluşturulması zorunlu hale gelmiştir.

Osmanlı Devleti'nin 19. yüzyılda Tanzimat dönemi gibi yeniliğe ve düzenlemeye açık bir döneme girmesi, kimsesiz ve muhtaç durumda olan çocuklarla ilgili de bazı adımların atılmasını sağlamıştır. Bununla birlikte artan ekonomik bunalım, yabancı devletlerin diplomatik baskıları, kaybedilen savaşlar, terkedilen topraklardan Osmanlı idaresindeki sahalara büyük göç akınlarının meydana gelmesi gibi sorunlar Osmanlı devlet ve toplum hayatını olumsuz etkilemiştir. Bu olumsuzluklardan en fazla etkilenenler ise çocuklar olmuştur. Her açıdan zayıf,

${ }^{80}$ Celal Bayar, Ben de Yazdım: Millî Mücadeleye Giriş, Sabah Yayınları, C.5, İstanbul 1997, s.58.

${ }^{81}$ Bakar, "agm", s. 577.

82 Çetinkaya, "agm", s. 147.

${ }^{83}$ Bayar, age, s. 58. 
aciz ve savunmasız olan çocukların, savaş ve göç gibi yaşam şartlarını ağırlaştıran hatta yaşamı tehdit eden bir ortamda hayata tutunmaları yetişkinlere göre daha zor olmuştur. Bu nedenle çok sayıda çocuk hayatını kaybetmiştir.

Göç yolculuğunu tamamlayarak Osmanlı topraklarına ulaşabilen çocuklardan bir kısmının aileleri tarafından satılmaları, evlatlık verilmeleri hatta işçi veya köle olarak kiralanmaları söz konusu olmuştur. Bir kısmı ise ailesini hatta akrabalarını tümüyle kaybetmiştir. Böylece Osmanlı toplumunda kimsesiz ve muhtaç çocuklar sınıfına bir de göç sırasında ailesini hatta akrabalarını kaybeden bir kimsesiz çocuklar sınıfı eklenmiştir. Kimsesiz çocuklar sınıfına dahil olan başka bir kesim de Birinci Dünya Savaşı döneminde ailelerinden ayrılmak zorunda kalan ya da ailelerini kaybeden gayrimüslim Ermeni tebaanın çocuklarıdır. Yani kimsesiz kalan çocuklar yalnız Müslüman çocuklardan ibaret olmamıştır. Osmanlı Devleti bu gruba mensup çocukların mümkün olduğunca Ermeni ve yabancılar nezdinde kalmaması için gayret göstermiş̧ir. Ancak gerek çocukların ihtiyaçlarının karşılanamaması gerekse Müslüman aileler yanında zorla tutuldukları suçlamasıyla karşılaşmamak için çocukların ailelerine, akrabalarına, yetimhanelere ya da mensup oldukları dinin ruhani reislerine teslimine karar verilmiştir.

Kimsesiz ve muhtaç duruma düşmüş olan çocukların korunması ve himayesinde ortaya çıan zafiyetler, çocukları kötü niyetli kişi, grup, kuruluş hatta devletlerin maddi ve manevi saldırılarına açık hale getirmiştir. Osmanlı Devleti’nin ekonomik ve siyasal açıdan baskı altında bulunması, yabanc1 misyoner veya temsilcilerin Osmanlı topraklarında faaliyet gösterebilmelerini kolaylaştırmıştır. Söz konusu faaliyetlerin en önemli araç ve hedeflerinden biri de kimsesiz çocuklar olmuştur. Kimsesiz çocukların bakımı ve ihtiyaçlarının giderilmesi şeklinde masum bir örtü ile örtülen yabancı faaliyetlerinin asıl hedefi, yerli ya da muhacirlerin kimsesiz çocuklarını ele geçirerek onların Hristiyanlaştırılması ve ülkelerine düşman haline getirilmesi olmuştur. Bu noktada gayrimüslimler, yabancı misyoner ve temsilcilere destek olmak ve kendileri de kimsesiz Müslüman çocukları zorla ve hile ile ele geçirerek Hristiyanlaştırmak yoluna gitmişlerdir. Gerek 19. yüzyılda gerekse Birinci Dünya Savaşı sonunda imzalanan Mondros Mütarekesi döneminde yabancı misyonerler ve gayrimüslim tebaa, kimsesiz çocuklara yönelik faaliyetlerini yabancı devletlerin destek ve himayesiyle sürdürmüşler, Osmanlı makamlarını ve Osmanlı kanunlarını hiçe saymışlardır. Bu nedenle kimsesiz çocuklara yönelik faaliyetlerinde şımarık ve zorbaca bir tavır sergilemişlerdir. Bu noktada başta Ermeniler olmak üzere gayrimüslim tebaanın bahanesi, Müslüman aileler yanına verilen Hristiyan çocuklar olmuştur. Osmanlı Devleti, Hristiyan Ermeni veya Rum çocuklarının iadesi noktasında hiçbir zorluk çıkarmamış hatta çocukların iadesini zorunlu kılmıştır. Buna karşıllı gayrimüslim ve yabancılar kimsesiz Müslüman çocukları hatta nüfuzlu Müslüman ailelerin çocuklarını zorla, yaygarayla ve hileyle ele geçirmeye ve Hristiyanlaştırmaya çalışmışlardır. Bu aşamada Osmanlı Devleti'nin duruma müdahalesi yabancı devletlerin temsilcileri hatta askeri güçleri tarafından engellenmiş, kimsesiz Müslüman çocuklar yabancı misyonerlerin, Ermeni ve Rum çetecilerin karşısında yalnız ve savunmasız kalmışlardır. 


\section{Kaynakça}

\section{Arşiv Belgeleri}

\section{T.C. Cumhurbaşkanlığı Osmanlı Arşivi (BOA) Belgeleri}

BOA, A.\} MKT.UM, 526/41, H.19.06.1278.

BOA, A.\} MKT.UM, 789/39, H.12.02.1281.

BOA, DH.KMS, 16/41, H. 18.08.1332.

BOA, DH.MKT, 1007/53, H.19.07.1323.

BOA, DH.MKT, 1517/56, H. 20.10.1305.

BOA, DH.ŞFR, 231/76, R. 21.11.1314.

BOA, DH.ŞFR, 236/16, R. 05.03.1315.

BOA, DH.ŞFR, 390/28, R. 14.09.1323.

BOA, DH.ȘFR, 518/23, R.16.02.1332.

BOA, DH.ȘFR, 63/142, H.26.06.1334.

BOA, DH.ŞFR, 63/276, H.08.071334.

BOA, DH.ŞFR, 96/248, H.19.05.1337.

BOA, DH.ŞFR, 97/104, H.08.06.1337.

BOA, DH.TMIK.M, 168/7, H. 29.01.1322.

BOA, DH.TMIK.M, 242/22, H. 16.03.1325.

BOA, DH.TMIK.M, 69/58, L: 7, H.26, 12.1316.

BOA, HR.İM, 59/50, Lef 2, M.02.01.1922.

BOA, HR.MKT, 3/70, H.11.04.1260.

BOA, HR.SFR.04, 421/10, M. 01.08.1918.

BOA, HR.SFR.04, 491/ 29, Lef 5, M.26.05.1917.

BOA, HR.SFR.1, 181/129, M.28.11.1895.

BOA, HR.SYS, 2029/1, Lef 23, M.29.01.1913.

BOA, HR.SYS, 71/32, M.24.03.1891.

BOA, HR.TH, 271/58, M. 21.07.1902.

BOA, HSD.HADB, 2/7, R. 29.10.1329.

BOA, MF.MKT, 1221/81, H.28.02.1335.

BOA, MF.MKT, 195/10, H. 30.07.1311.

BOA, MF.MKT, 203/30, Lef 5, H.22.10.1311.

BOA, Y.MTV, 185/80, H. 21.08.1316.

BOA, Y.PRK.UM, 20/112, H.07.07.1308.

BOA, Y.PRK.UM, 46/29, H.10.01.1317.

BOA, Y.PRK.UM, 46/64, H. 29.01.1317.

BOA, YEE.KP, 8/798, H. 28.08.1316.

\section{Kitap ve Makaleler}

AĞANOĞLU, H. Yıldırım, Osmanlı'dan Cumhuriyete Balkanların Makus Tarihi Göç, Kum Saati Yayınları, İstanbul 2001, s. 32.

AKÇA, Bayram, “Antep (Ayıntap) Protestan Okulu ve Ermeni Meselesi”, Ermeni Araştırmaları, Yaz-Sonbahar 2004, C.4, S.14-15, Avrasya Stratejik Araştırmalar Merkezi Yayınları, Ankara 1994, s. 42-49.

ALAN, Gülbadi, “Amerikan Board Okullarında Yürütülen Misyonerlik Faaliyetleri”, İslâmî Araştırmalar Dergisi, C. 20, S.4, Y. 2007, s.464-475. 
ARI, Abdüsselam, "Yetim”, Türkiye Diyanet Vakfi İslâm Ansiklopedisi, C.43, İstanbul 2003, s.501-503.

BAKAR, Bülent, "Mondros Mütarekesi'nden Sonra Yaşanan Önemli Bir Problem: Türk ve Ermeni Yetimleri Sorunu", Atatürk Araştırma Merkezi Dergisi, C.21, S.62, Y1l 2005, s.569-588.

BARDAKOĞLU, Ali, "Bulûğg”, Türkiye Diyanet Vakfı İslâm Ansiklopedisi, C. 6, İstanbul 1992, s. 413-414.

BAYAR, Celal, Ben de Yazdım: Millî Mücadeleye Giriş, Sabah Yayınları, C.5, İstanbul 1997.

BEYOĞLU, Süleyman, "Ermeni Tehciri ve İhtida", Yakın Dönem Türkiye Araştırmaları, S.6, 2004, s.1-18.

ÇETINKAYA, Göktürk Selma, "Tehcir Sonrası Müslüman Çocuklara El Konulması Meselesi”, Tarih Dergisi, S.65, İstanbul 2017/1, s.131-166.

DERINGIIL, Selim, 19. Yüzyıl Osmanlı Devleti'nde İhtida ve Irtidad, Çev. Ayşen Anadol-Taciser Ulaş Belge, İletişim Yayınları, İstanbul 2017.

DEVELLİĞ̆LU, Ferit, Osmanlıca-Türkçe Ansiklopedik Lûgat, Aydın Kitabevi Yayınları, Ankara 1997, s. 541, 555.

DİNGEÇ, Emine, “Amerikan Misyoner Okullarının Ermeni Ayrılıkçı Hareketlerindeki Yeri”, Hoşgörüden Yol Ayrımına Ermeniler, C.2, Erciyes Üniversitesi Yayını, Kayseri 2009, s. 29-50.

GAZANKER, Emine, XVI. ve XVII. Yüzylllarda Osmanlı Toplumunda Kimsesiz Çocuklar ve Evlatlıklar, T.C. Bahçeşehir Üniversitesi, Sosyal Bilimler Enstitüsü, Yayınlanmamış Yüksek Lisans Tezi, İstanbul 2014, s.28, 30, 31.

GÜNDÜZ, Şinasi, "Misyonerlik" Türkiye Diyanet Vakfi İslâm Ansiklopedisi, C.30, İstanbul 2005, s.193-199.

HÖKELEKLİ, Hayati, “Çocuk” Türkiye Diyanet Vakfı İslâm Ansiklopedisi, C. 8, İstanbul 1993, s. 355-359.

İMAMOĞLU, Hüseyin Vehbi, "93 Harbinden Sonra Balkanlardan Anadolu'ya Göçler”, Geçmişten Günümüze Göç I, Canik Belediyesi Kültür Yayınları, Samsun 2017, s.140-141.

İPEK, Nedim, Imparatorluktan Ulus Devlete Göçler, Serander Yayınları, Trabzon 2006, s.32.

İPEK, Nedim, Rumeli'den Anadolu’ya Türk Göçleri (1877-1890), Türk Tarih Kurumu Yayınları, Ankara 1999, s. 1.

KARATAŞ, Zekai, “Osmanlı Devleti’nde Korunmaya Muhtaç Çocuklara Yönelik Sosyal Hizmet Uygulamaları", Manevi Temelli Sosyal Hizmet Araştırmaları Dergisi, C. 1, S. 1, Ocak 2015, s.16-31.

KEHA, Murathan, “1877-1878 Osmanlı Rus Harbi’ne Kadar Yaşanan Kırım Kafkas Göçleri ve Erzurum'un Durumu”, Ekev Akademi Dergisi, Y11 17, S. 57, Güz 2013, s. 94.

KILIÇ İskender Pelin, "Mehmed Esad Safvet Paşa'nın Devair Müfettişliği Sırasında Muhacirler ve Muhacir Çocuklarıyla İlgili Görüşleri ve Bu Konudaki Çalışmaları", History Studies, C.9, S.3, Eylül 2017, s.111-120. 
KOCAOĞLU, Burak, "Bir İskân Bölgesi Cebel-i Bereket Sancağı ve Yaşanan Sorunlar", Türkiye'nin Bölgesel Sorunları "Osmanlı'dan Günümüze” Ortadoğu, Edt. Mehmet ÇelikAlev Duran, Hiperlink Yayınları, İstanbul 2020, s.255-279.

KOCAOĞLU, Burak, “Osmanlı Devleti'nde Çocukların İhtida Meselesi (1886-1914), History Studies, 12/3, Haziran 2020, s.789-805.

KOÇ, Mustafa, "Gelişim Psikolojisi Açısından Ergenlik Dönemi ve Genel Özellikleri”, Erciyes Üniversitesi Sosyal Bilimler Enstitüsü Dergisi, S.17, Kayseri, 2004/2, s.231-256.

MCCARTHY, Justin, Ölüm ve Sürgün Osmanlı Müslümanlarının Etnik Kıyımı 1821-1922, Çev. Fatma Sarıkaya, Türk Tarih Kurumu Yayınları, Ankara 2014.

MÜEZZİNOĞLU, Ersin, "I. Dünya Savaşı Esnasında Yetim ve Öksüz Çocukların Himayesi ve Eğitimi: Darüleytamlar", History Studies, C.4, S.1, Mart 2012, s. 399-417.

ÖZBAY, Ferhunde “1911-1922 Yıllarında Anadolu'nun Kimsesiz Kız Çocukları”, Savaş Çocuklarl, Öksüzler ve Yetimler, Edt. Emine Gürsoy Naskali-Aylin Koç, İstanbul 2003, s.105-118.

ÖZCAN, Tahsin, "Osmanlı Toplumunda Yetimlerin Himayesi ve Eytâm Sandıkları", İstanbul Üniversitesi Illahiyat Fakültesi Dergisi, S.14, Y.2006, s. 103-121.

ÖZÇELİK, İsmail, Ermeni Sorunu ve Gerçekler, Gündüz Eğitim ve Yayıncılık, Ankara 2005.

ÖZTÜRK, Cemil, "Islahhane”, Türkiye Diyanet Vakfi İslâm Ansiklopedisi, C. 19, İstanbul 1999, s.190-191.

POLAT, Bengül - AYVAZ, Ratip, “İngiliz Misyonerlik Faaliyetlerinin Osmanlı Devleti'nin Y1kılış Sürecine Etkileri”, Atatürk Yolu Dergisi, Ankara Üniversitesi Türk İnkılap Tarihi Enstitüsü, S. 61, Güz 2017, s. 1-45.

SARIBAL, İsmet, Osmanlı Devleti'nde Muhaceret, İskân ve Entegrasyon Bursa Sancağı Örneği (1845-1908),İdeal Kültür Yayınc1lık, İstanbul 2018, s. 135.

TÜRKKAN, Hakan, “Osmanlı Devleti’nde Muhtaç ve Kimsesiz Çocukların Karş1lıksız Eğitimi“, VI. Uluslararası Tarih Eğitimi Sempozyumu, Bolu, 10-12 Ekim 2019, s.474480.

YAZICI, Nesimi, "Osmanlılarda Yetimlerin Korunması Üzerine Bazı Değerlendirmeler", $A \ddot{U I F D}$, XLVIII, S. 1, 2007, s. 4.

YURTSEVEN, Yılmaz, "1917 Tarihli Hukuk-1 Aile Kararnamesi ve Osmanlı Aile Hukukuna Getirdiği Yenilikler”, Selçuk Üniversitesi Hukuk Fakültesi Dergisi, C.11, S. 1-2, Haziran 2003, s.199-250. 


\section{Hakan Türkkan}

\section{EKLER}

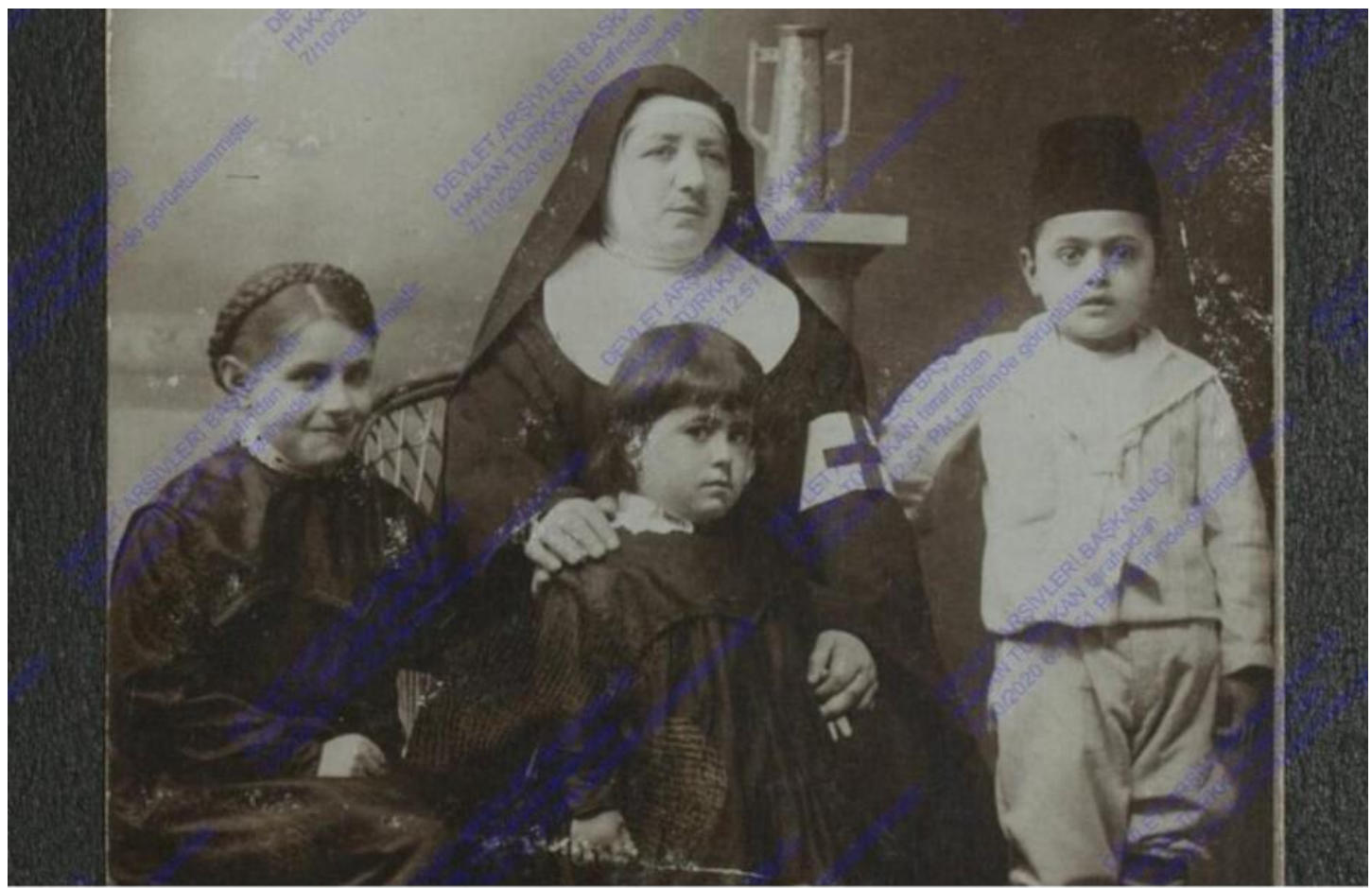

Volume 12

Issue 5

October

Ek 1: 32. Alay Yüzbaşılarından Asım Efendi’nin Şehit olan eşinden kalan ve Dedeağaç Fransız misyonerleri himayesinde kalan çocuklarına ait fotoğraf (BOA, HSD.HADB (Satın Alınan, Hacı Adil Bey Evrakl), 2/7, R. 29.10.1329). 